\title{
Biogas production for organic waste management: a case study of canteen's organic waste in Solid Waste Management Technical Support Center, Lalitpur, Nepal
}

\author{
S. Shrestha ${ }^{1^{*}}$, N. P. Chaulagain ${ }^{2}$, K. R. Shrestha ${ }^{3}$ \\ ${ }^{1}$ Central Department of Environmental Science, Tribhuvan University, Kathmandu, Nepal \\ ${ }^{2}$ Nepal Energy Efficiency Programme, Khumaltar, Lalitpur, Nepal \\ ${ }^{3}$ Center for Energy and Environment Nepal, Bhotebahal-11, Kathmandu, Nepal
}

\begin{abstract}
Management of solid waste is one of the major challenges faced by the municipalities. Solid waste mainly comprises of organic waste. Proper management of organic waste helps minimize solid waste problem. This study was carried out to assess the production of biogas from canteen's organic waste as a solution for management of organic waste in Solid Waste Management Technical Support Centre, Lalitpur using innovative urban biogas plant with capacity 1,275 liters for 48 days. The physicochemical parameters of canteen's waste and bio-slurry were analyzed. Similarly, volume of biogas, volume of methane and carbon dioxide in biogas produced were measured and $\mathrm{CO}_{2}$ reduction from biogas plant was identified. The average values of physicochemical parameters of canteen's waste lied within the optimum range for biogas production. The biogas plant produced 22.03 liters $/ \mathrm{kg}$ of waste and 120.47 liters/day of biogas. The produced biogas contained $48.89 \%$ methane and $39.11 \%$ carbon dioxide on average. The biogas plant could reduce 3.20 tones of $\mathrm{CO}_{2}$ equivalent per annum from $262.50 \mathrm{~kg}$ of waste fed for 48 days. The values of nitrogen, phosphorus and potassium of bio-slurry indicated it as a better fertilizer. Shapiro-Wilk test showed that the $p$-value of collected data were greater than 0.05 indicating normal distribution. Linear regression between ambient temperature and biogas production showed that the $p$-value less than 0.05 indicating significant relationship between them $\left(r^{2}=0.08\right)$. The estimated return period of the invested money was 9.5 months in kerosene substitution or 9.7 months in firewood substitution or 9.5 months in LPG substitution. Similarly, the estimated average rate of return was $125.26 \%$ in kerosene substitution or $123.72 \%$ in firewood substitution or $125.01 \%$ in LPG substitution. These results indicated that biogas production using innovative urban biogas plant is better solution for organic waste management. Further extensive and lagre scale research need to be carried out for the optimization of the biogas plant.
\end{abstract}

Key words: Bio-slurry, $\mathrm{CO}_{2}$ reduction, fertilizer, methane, urban biogas plant

\section{Introduction}

Urbanization and rapid population growth are the main issues worldwide creating increased generation of solid waste per unit area (Thenabadu, 2014). Particularly, urban and semi-urban areas of developing and poor countries are facing great challenges in managing solid waste (Thenabadu, 2014; Hwa, 2007). Nepal is one of the developing countries facing such environmental problems due to rapid and uncontrolled urbanization, lack of public awareness and poor management by municipalities along with unsanitary waste disposal and management (ADB, 2013). According to the survey of ADB (2013), the average municipal solid waste (MSW) generation of 58 municipalities in Nepal was 317 grams per capita per day. The study showed that MSW composed of $56 \%$ organic waste, $16 \%$ plastics, $16 \%$ paper and paper products, $3 \%$ glass, $2 \%$

*Corresponding author, email address: sandilashrestha@gmail.com metals, $2 \%$ textiles, $1 \%$ leather and rubber and $4 \%$ others; where organic waste accounted the highest percent.

Organic waste such as kitchen waste is regarded as waste and thrown, which then becomes the source of the pollution. This pollution results in many environmental problems as well as health problems leading to many diseases (Shakya et al., 2009). For the management of the food waste, people prefer to compost the waste for using as manure in the field and ignore the energy that could be obtained from the waste (Deressa et al., 2015). In this context, anaerobic digestion of organic waste could be better solution, as it minimizes the volume and mass of organic waste and also recovers energy at source at the same time (Kader et al., 2015). 
Anaerobic digestion is the process of decomposition of biodegradable substance by microorganisms in the absence of oxygen (Thenabadu, 2014). The end-products of anaerobic digestion are gas containing mainly methane and carbon dioxide, referred to as biogas; and a slurry or solid residue (Papacz, 2011). Biogas is the most important alternative and useful energy source which is technically feasible and economically viable than other approaches (Gautam, 2012).

This study was carried out with the aim of producing biogas from canteen's waste (kitchen waste) in urban area (Lalitpur) using innovative urban biogas plant (Jeeban's model) (Fig. 1).

\section{Materials and Methods}

The study was carried out in Solid Waste Management Technical Support Centre (SWMTSC), Pulchowk, Lalitpur (Fig. 2) using Jeeban's model urban biogas plant (Fig. 1). SWMTSC lies in Lalitpur Metropolitan City, Province no. 3. The SWMTSC falls under Ministry of Federal Affairs and Local Development (Ministry of Federal Affairs and Local Development (MoFALD). The geographical coordinates of SWMTSC are $27^{\circ} 40^{\prime} \mathrm{N}$ and $85^{\circ} 19^{\prime} \mathrm{E}$. It is situated at an elevation of $1305 \mathrm{~m}$ (GPS, Etrex 10, GARMIN).

The urban biogas plant has fixed digester and its capacity is 1,275 litres (Fig. 1). For total trapping of gas, biogas plant was insulated with plastic sheet and glass wool (Fig. 2).

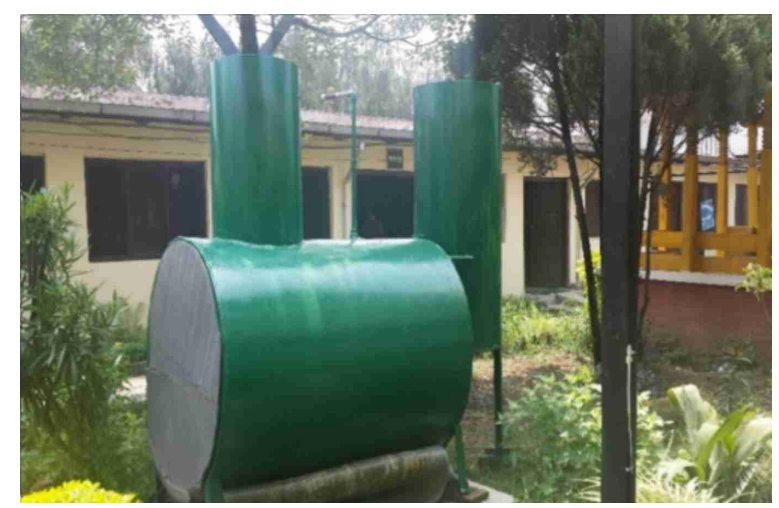

Figure 1 Jeeban's model biogas plant

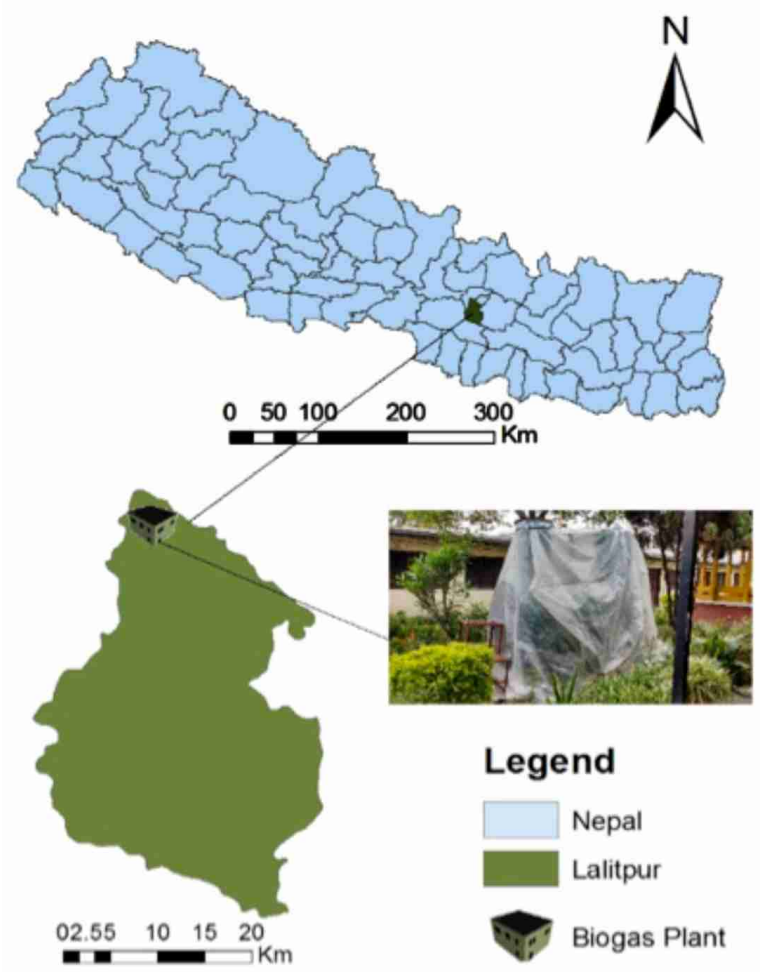

Figure 2 Location of SWMTSC where biogas plant was installed 


\section{Composition of organic waste collected}

The food (kitchen waste) was collected in the four buckets provided to the canteen of SWMTSC. Composition of the collected waste was identified by visual estimation. With the help of the eyes, the composition of the waste was identified and categorized according to its amount present in the collected waste.

\section{Sampling of waste and slurry sample}

For the representative waste sample, $50 \mathrm{~g}$ of waste, each from four buckets, was kept together and mixed. This sample was air dried, ground, and sieved. Thus, prepared waste sample was used for laboratory analysis. The bio-slurry was also air dried, ground, and sieved. This sample was used for laboratory analysis.

\section{Laboratory analysis}

The laboratory analysis of waste and bio-slurry sample was done for three times at an interval of one week. It was performed using standard methods and instruments (Table 1).

\section{Field analysis}

Various parameters and instruments used for field parameters analysis are shown in Table 2.

\section{Statistical analysis}

Data collected were analyzed using R-programming ( $R$ version 3.4.0). To test the normal distribution of the population ShapiroWilk normality test was performed as the sample number was less than 50 . Simple linear regression was performed to determine the relationship between ambient temperature and biogas production.

\section{Economic analysis}

Economic analysis was performed on the basis of energy content and market price of fuels with assumptions. Simple payback period was determined by dividing total cost of the biogas plant to the total cost savings. Average rate of return was calculated by dividing the subtracted value of current and original cost of biogas plant with the original cost of biogas plant and multiplying the obtained value with 100 , as given in the equation.

Averege rate of return $=\frac{(\text { Current cost-Original cost }) \text { of biogas plant }}{\text { Original cost of biogas plant }} \times 100$

\section{Results and Discussion Composition of canteen's organic waste}

The collected canteen's organic waste was composed of both raw and cooked foods (Fig. 3). The canteen's organic waste contained highest percentage of vegetables peels and leftover. The feeding material consisted of mixed organic waste generated daily in the kitchen.

\section{Values of physicochemical parameters of input waste and bio-slurry}

The average values of physicochemical parameters of input waste and bio-slurry are shown in Table 3. For the production of biogas, $\mathrm{pH}$ of the input material should be in between 6 and 7, C: $\mathrm{N}$ ratio should be 20-30:1 and total solid should be 5-10\% (Karki et al., 2015). The obtained value of $\mathrm{pH}$ of waste was 5.99 which was found to be within the range and was suitable for the production

Table 1: Parameters, methods and instruments for lab analysis

\begin{tabular}{clll}
\hline S.N. & Parameters & Methods & Instruments \\
\hline 1. & Total solid & Oven drying & Hot air oven and dessicator \\
2. & Volatile solid & Gravimetric & Muffle furnace and dessicator \\
3. & Organic matter & Modified Walkley \& Black & Burette, pipette \\
4. & Nitrogen & Kjeldahl Digestion & Kjeldahl distillation assembly \\
5. & Carbon & Modified Walkley \& Black & - \\
6. & C:N ratio & From 4 and 5 (Division) & - \\
7. & Phosphorus & Ammonium molybdate & Spectrophotometer \\
8. & Potassium & Ammonium acetate & Flame photometer \\
9. & pH & Potentiometric & pH meter \\
\hline
\end{tabular}

Table 2: Parameters and instruments for field analysis

\begin{tabular}{lll}
\hline S.N. & Parameters & Instruments \\
\hline 1. & Temperature & Lab thermometer and indoor/outdoor thermometer \\
2. & Volume of methane and $\mathrm{CO}_{2}$ & Gas analyzer (SAW4 Multi-gas Detecting Alarm) \\
3. & Pressure & Pressure gauze \\
4. & Volume of biogas & Gas flow meter(Chint ZT-G2.5S) \\
\hline
\end{tabular}


of biogas. This meant that $\mathrm{pH}$ of waste was appropriate for the survival of methane producing bacteria. Similarly, the $\mathrm{pH}$ of bioslurry was found to be alkaline ( $\mathrm{pH}$ 8.99). Methanogenic bacteria best thrive under neutral to alkaline conditions (Thenabadu, 2014). The $\mathrm{pH}$ of bio-slurry indicated that methane producing bacteria are growing and digesting the waste to produce biogas. Organic matter and carbon content in bio-slurry were found to be less in compared to canteen's waste. This may be because of the utilization of organic matter by the methanogenic bacteria for the digestion process. This also indicated that there was proper digestion of feeding materials. The C:N ratio was 19.85:1 which lied within the range reported by Karki et al. (2015) suggesting canteen's waste to be suitable for the biogas production. While, the total solid was found to be $14 \%$, which was little higher, may be because of lesser moisture content in the waste. Similarly, the digested slurry contains $1.60 \%$ nitrogen, $1.55 \%$ phosphorus and $1.00 \%$ potassium (Karki et al., 2015). The obtained value of nitrogen was $1.69 \%$ which was little higher than this range and the value of phosphorus was found to be $0.88 \%$ which is lesser. However, these values were near to the range indicating that the bio-slurry could be used as a fertilizer for crop production.

\section{Measurement of biogas production}

The total volume of biogas within the data collection period ( 48 days) was calculated to be 5,782 liters and the total weight of waste fed in the digester within that period was calculated to be $262.50 \mathrm{~kg}$. Hence, $1 \mathrm{~kg}$ of canteen's waste was capable of generating 22.03 liters of biogas in average. Sapkota et al. (2012) obtained $32.12 \mathrm{l} / \mathrm{kg}$ of biogas from kitchen waste. According to Zupancic and Grilc (2012), municipal organic waste contains $0.5-0.8 \mathrm{~m}^{3} / \mathrm{kg}$ of Volatile Solid (VS). The obtained volume of biogas in this study was found to be less than both studies. The low production of biogas may be because of the improper digestion of the canteen's waste, overfeeding of the waste in the digester and the shade of the tree located behind the biogas plant preventing the direct sun rays to the bio-digester. Similarly, the data collection period was 48 days. Hence, it was calculated that the biogas plant was capable of producing 120.46 liters of biogas in a day which could boil four liters of water.

\section{Composition of methane and carbon dioxide}

The average methane content was calculated to be $48.89 \%$ and that of carbon dioxide was calculated to be $39.11 \%$. According to Karki et al. (2015), biogas consists of 50-70\% of methane and 30$40 \%$ of carbon dioxide. The obtained percentage of methane was near to the range and carbon dioxide was within the range. Lesser volume of methane may be due to presence of carbohydrates like potato peels, cooked rice and food leftover in the feeding material.

\section{Reduction in $\mathrm{CO}_{2}$ emission from the biogas plant}

The annual reduction of $\mathrm{CO}_{2}$ emission from the operation of the biogas plant is shown in Table 4. Since the government had fixed 100 days as public holidays for 2074 B.S. (2017/2018) (Himalayan News Service, 2017); so 100 days have been deducted from annual days (365 days) and the analysis was done for office working days only, i.e. for 265 days. The Table 4 showed that using urban biogas plant, 3.20 tonnes of $\mathrm{CO}_{2}$ equivalent could be reduced in a year from $262.50 \mathrm{~kg}$ of canteen's waste. It revealed that even a small volume of bio-digester can help in reduction of carbon dioxide.

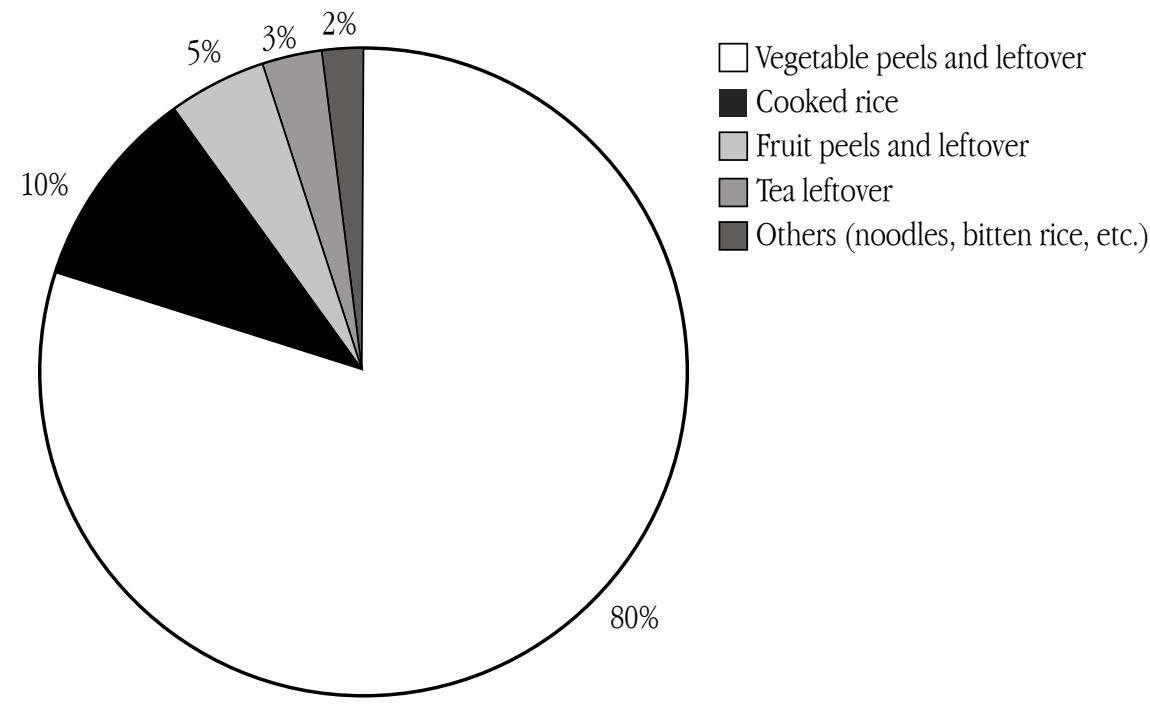

Figure 3. Composition of canteen's organic waste

\section{蛹TU-CDES}


Table 3 Average values of physicochemical parameters

\begin{tabular}{lcccc}
\hline Parameters & $\begin{array}{c}\text { Canteen's waste } \\
\text { (Average value) }\end{array}$ & $\begin{array}{c}\text { Optimum } \\
\text { value* }\end{array}$ & $\begin{array}{c}\text { Bio-slurry } \\
\text { (Average value) }\end{array}$ & $\begin{array}{c}\text { Optimum } \\
\text { value* (\%) }\end{array}$ \\
\hline pH & 5.99 & $6-7$ & 8.99 & - \\
Organic matter (\%) & 58.80 & - & 54.31 & - \\
Carbon (\%) & 34.61 & - & 31.50 & - \\
Nitrogen (\%) & 1.75 & - & 1.69 & 1.60 \\
C:N ratio & $19.85: 1$ & $20-30: 1$ & $19.90: 1$ & - \\
Phosphorus (\%) & 0.93 & - & 0.88 & 1.55 \\
Potassium (ppm) & 55.00 & - & 56.33 & - \\
Total solid (\%) & 14.00 & $5-10$ & 0.72 & - \\
Volatile solid (\%) & 99.26 & - & 99.31 & - \\
\hline
\end{tabular}

*Karki et al. (2015)

Table $4 \mathrm{CO}_{2}$ Equivalent calculation from the biogas plant

\begin{tabular}{|c|c|c|}
\hline $\begin{array}{l}\text { Weight of canteen's waste } \\
\text { collected in } 48 \text { days }\end{array}$ & 262.50 & $\mathrm{Kg}$ \\
\hline Conversion factor* & 2.20 & $\mathrm{~kg}$ of $\mathrm{CO}_{2}$ equivalent \\
\hline Total $\mathrm{CO}_{2}$ equivalent in 48 days & 0.58 & Tonnes of $\mathrm{CO}_{2}$ equivalent \\
\hline Total $\mathrm{CO}_{2}$ equivalent/annum** & 3.20 & Tonnes of $\mathrm{CO}_{2}$ equivalent \\
\hline
\end{tabular}

*Dhakal et al. (2015); **Calculated for 265 days

\section{Statistical data}

The result of Shapiro-Wilk normality test is presented in Table 5. The p-value obtained in all the data was found to be $>0.05$ suggesting that the collected data was acceptable, good and normal. Here, the obtained $p$-value was $<0.05$. This showed that there was significant relationship between ambient temperature and biogas production.

Using simple linear regression in R-programming, relationship between ambient temperature and biogas production has been determined. The output of simple linear regression is shown in Table 6.
Table 5 Shapiro-Wilk normality test value

\begin{tabular}{lc}
\hline Data & p-value \\
\hline Weight & 0.2124 \\
Biogas production & 0.0875 \\
Ambient temperature & 0.9315 \\
Inlet's temperature & 0.1298 \\
\hline
\end{tabular}

\section{Economic analysis}

The calculated cost-benefit estimation of kerosene, firewood or LPG substitution in terms of biogas has been shown in Table 7, 8 and 9 respectively.

The cost benefit estimation showed that if the benefits obtained from bio-slurry is also considered, the invested money will be returned in less than one year to substitute kerosene or firewood or LPG by a biogas plant. Similarly, the average rate of return to substitute any of the three fuels by the biogas plant was found to be more than $100 \%$. This indicated that this biogas plant is attractive from investment point of view and is economically feasible.

Table 6 Relationship between ambient temperature and biogas production

\begin{tabular}{lcccc}
\hline & Estimate & Std. Error & t value & $\operatorname{Pr}(>|\mathrm{t}|)$ \\
\hline (Intercept) & 249.184 & 63.684 & 3.913 & $0.000299 * * *$ \\
Ambient Temperature & -4.727 & 2.325 & -2.033 & $0.047805 *$ \\
Residual standard error & & 48.04 on 46 degrees of freedom & \\
Multiple R-squared & & 0.08247 & \\
Adjusted R-squared & & 0.06253 & \\
F-statistic & & 4.135 on 1 and $46 \mathrm{DF}$ & \\
p-value & & 0.04781 & \\
\hline
\end{tabular}

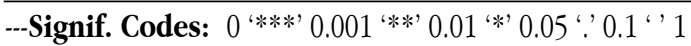


Table 7 Cost-benefit estimation of kerosene substitution in terms of biogas

\begin{tabular}{ccccccc}
\hline $\begin{array}{c}\text { Total energy } \\
\text { available/ } \\
\text { annum } \\
(\mathrm{MJ})\end{array}$ & $\begin{array}{c}\text { Annual cost } \\
\text { savings in } \\
\text { kerosene } \\
\text { (NRs.) }\end{array}$ & $\begin{array}{c}\text { Cost of } \\
\text { bio-slurry/ } \\
\text { annum } \\
\text { (NRs.) }\end{array}$ & $\begin{array}{c}\text { Total cost } \\
\text { savings in } \\
\text { kerosene } \\
\text { (NRs.) }\end{array}$ & $\begin{array}{c}\text { Investment } \\
\text { cost }\end{array}$ & $\begin{array}{c}\text { Simple } \\
\text { payback } \\
\text { period } \\
\text { (NRs. })\end{array}$ & $\begin{array}{c}\text { Average } \\
\text { rate of } \\
\text { return } \\
\%\end{array}$ \\
\hline 604.20 & $1,277.24$ & $62,606.25$ & $63,883.49$ & 51,000 & 9.5 & 125.26 \\
\hline
\end{tabular}

Table 8 Cost-benefit estimation of firewood substitution in terms of biogas

\begin{tabular}{ccccccc}
\hline $\begin{array}{c}\text { Total energy } \\
\text { available/ } \\
\text { annum } \\
(\mathrm{MJ})\end{array}$ & $\begin{array}{c}\text { Annual cost } \\
\text { savings in } \\
\text { firewood } \\
\text { (NRs.) }\end{array}$ & $\begin{array}{c}\text { Cost of } \\
\text { bio-slurry/ } \\
\text { annum } \\
\text { (NRs.) }\end{array}$ & $\begin{array}{c}\text { Total cost } \\
\text { savings in } \\
\text { firewood } \\
\text { (NRs.) }\end{array}$ & $\begin{array}{c}\text { Investment } \\
\text { cost }\end{array}$ & $\begin{array}{c}\text { Simple } \\
\text { payback } \\
\text { period } \\
\text { (NRs.) }\end{array}$ & $\begin{array}{c}\text { Average } \\
\text { rate of } \\
\text { return }\end{array}$ \\
\hline 604.20 & 489.90 & $62,606.25$ & $63,096.15$ & 51,000 & 9.7 & 123.72 \\
\hline
\end{tabular}

Table 9 Cost-benefit estimation of LPG substitution in terms of biogas

\begin{tabular}{ccccccc}
\hline $\begin{array}{c}\text { Total energy } \\
\text { available/ } \\
\text { annum } \\
(\mathrm{MJ})\end{array}$ & $\begin{array}{c}\text { Annual cost } \\
\text { savings in } \\
\text { LPG }\end{array}$ & $\begin{array}{c}\text { Cost of } \\
\text { bio-slurry/ } \\
\text { annum } \\
\text { (NRs. })\end{array}$ & $\begin{array}{c}\text { Total cost } \\
\text { savings in } \\
\text { (NRG. }\end{array}$ & $\begin{array}{c}\text { Investment } \\
\text { cost }\end{array}$ & $\begin{array}{c}\text { Simple } \\
\text { payback } \\
\text { period }\end{array}$ & $\begin{array}{c}\text { Average } \\
\text { rate of } \\
\text { return } \\
\%\end{array}$ \\
\hline 604.20 & $1,150.51$ & $62,606.25$ & $63,756.76$ & 51,000 & 9.5 & 125.01 \\
\hline
\end{tabular}

\section{Conclusion}

The obtained values of physicochemical parameters of canteen's waste indicated that kitchen waste is an appropriate material for anaerobic digestion. The present study showed that one $\mathrm{kg}$ of waste was able to produce 22.03 liters of biogas and 120.46 liters of biogas was produced in a day. So, if this kind of biogas plant is kept in the household of urban areas, the problem of organic waste management faced by the municipalities could be solved.

Another important benefits provided by anaerobic digestion is the production of energy or fuel, i.e. biogas which can be used for cooking and the residue, i.e. bio-slurry can be used for crop production. The study showed that biogas produced in a day was able to boil 4 liters of water daily. So, the energy produced can act as a supplement fuel for cooking purpose for urban people suffering from energy crisis. During the study, bio-slurry produced was found to be blackish with lesser odor and within optimum values of NPK. Hence, this residue could be used as a fertilizer in the garden.

Besides these benefits to the people, biogas also helps to protect environment from the GHGs emission. The study showed that even a small quantity of waste $(262.50 \mathrm{~kg})$ fed in the biogas plant was able to reduce a greater quantity of carbon dioxide emission (3.20 tones of $\mathrm{CO}_{2}$ equivalent per annum). So, if organic waste of the urban households could be utilized for biogas production, reduction of carbon dioxide emission could be even greater as compared to the present study value.
The urban biogas plant is economically feasible as well. The benefits obtained from biogas and bio-slurry makes this plant suitable and profitable for the investors. It can be concluded that biogas production is better solution to manage organic waste.

\section{Acknowledgements}

Authors are thankful to the Central Department of Environmental Science, Tribhuvan University for providing facilities to conduct this research work. Thanks are due to Solid Waste Management Technical Support Centre, Pulchowk for providing the facilities to conduct the research work.

\section{References}

ADB (2013). Solid waste management in Nepal. Current status and policy recommendations. Asian Development Bank, Mandaluyaong City, Philippines.

Deressa, L., Libsu, S., Chavan, R.B., Manayeu, D., \& Dabassa, A. (2015). Production of biogas from fruits and vegetable wastes mixed with different wastes. Environment and Ecology Research, 3(3), 65-71. doi: 10.13189/eer.2015.030303.

Dhakal, N., Karki, A., \& Nakarmi, M. (2015). Waste to energy: management of biodegradable healthcare waste through anaerobic digestion. Nepal Journal of Science and Technology, 16(1), 41-48.

\section{能 TU-CDES}


Gautam, D.R. (2012). Utilization and benefits of biogas in the settlements along the Siddhartha Highway in Syangja district, Nepal. The Third Pole: Journal of Geographical Education, 11/12, 6-11.

Hwa, T.J. (2007). Overview of solid waste management in Asian countries. Solid Waste Management: Issues and Challenges in Asia. Asian Productivity Organization. 1-2-10 Hirakawacho, Chiyoda-ku, Tokyo 102-0093, Japan.

Himalayan News Service (2017). Govt fixes 100 public holidays for 2074 BS. The Himalayan Times. Retrieved September 9, 2017 from .com/kathmandu/government-fixes-100-publicholidays-2074-bs/.

Kader, F., Baky, A. H., Khan, M. N. H., \& Chowdhury, H. A. (2015). Production of biogas by anaerobic digestion of food waste and process simulation. American Journal of Mechanical Engineering. 3(3), 79-83.

Karki, A.B., Nakarmi, A.M., Dhital, R.M., Sharma, I., \& Kumar, P. (2015). Biogas as renewable source of energy in Nepal. Theory and development. Alternative Energy Promotion Center (AEPC), Lalitpur, Nepal.

MoFALD (2015). Brief introduction. Lalitpur Metropolitan City. Ministry of Federal Affairs and Local Development, Government of Nepal, Kathmandu.
Papacz, W. (2011). Biogas as vehicle fuel. Journal of KONES Powertrain and Transport. 18(1), 403-410.

Sapkota, T., Aryal, J., Thapa, S., \& Karki, A.B. (2012). Biogas production from anaerobic digestion of different biodegradable materials. Nepal Journal of Science and Technology, 13(2), 123-128.

Shakya, A. K., Das, K.L., \& Shah, R. (2009). Design and fabrication of a kitchen waste based biogas plant $\varepsilon$ testing with different feed materials. A project report submitted to department of mechanical engineering, Lalitpur, Nepal.

Thenabadu, M. (2014). Anaerobic digestion of food and market waste; waste characterization, biomethane potential and bio reactor design: A case study in Sri Lanka. Master of Science Thesis. Kungliga Tekniska Hogskolan (KTH) School of Industrial Engineering and Management. Energy Technology EGI-2014-109 MSC EKV1069. Division of Heat and Power. University of Gavle.

Zupancic, G.D., \& Grilc, V. (2012). Anaerobic Treatment and Biogas Production from Organic Waste. Management of Organic Waste. Intech. Europe. DOI: 10.5772/32756. 